\title{
For the further training of individuals in neurosurgery: a history of the William P. Van Wagenen Fellowship
}

\author{
Tyler M. Schmidt, DO, ${ }^{1}$ lan A. DeAndrea-Lazarus, MPH, ${ }^{1}$ Kristopher T. Kimmell, MD, ${ }^{1}$ \\ G. Edward Vates, MD, PhD, ${ }^{1}$ Stephen J. Haines, MD, ${ }^{2}$ and Webster H. Pilcher, MD, PhD'

\begin{abstract}
'Department of Neurosurgery, University of Rochester, New York; and 'Department of Neurosurgery, University of Minnesota,
\end{abstract} \\ Minneapolis, Minnesota
}

\begin{abstract}
The William P. Van Wagenen Fellowship, celebrating its 50th anniversary, is an annual award given by the AANS and administered by the Neurosurgery Research and Education Foundation (NREF). Named after its benefactor, Dr. William Van Wagenen, the fellowship continues his legacy of mentorship and innovation. As the premier research award for young neurosurgeons, it has provided a foundation for career development for many thought leaders in the field. The award was created in the spirit of Van Wagenen's belief in collaboration with other institutions as a means of refining neurosurgical technique, creating new research initiatives, and improving patient outcomes. Van Wagenen's commitment was informed by his early experiences in neurosurgery with his mentor Dr. Harvey Cushing, who helped to fund Van Wagenen's scientific endeavors in Europe. This journey catalyzed Van Wagenen's lifelong commitment to mentorship, which is exemplified by his instrumental role in the creation of the Harvey Cushing Society, now the AANS. Over the last 50 years, the recipients of this award have used the endowment to lay the groundwork for many scientific and technical innovations in neurosurgery. The fellowship remains an unmatched opportunity to explore new lines of investigation, foster academic and research goals, incorporate new technology and skills into American neurosurgical practice, and motivate young neurosurgeons to transform the field. The legacy of mentorship, scientific inquiry, and clinical excellence personified by Cushing and Van Wagenen is memorialized in the William P. Van Wagenen Fellowship.

https://thejns.org/doi/abs/10.3171/2017.10.JNS17999
\end{abstract}

KEYWORDS William P. Van Wagenen Fellowship; Neurosurgery Research and Education Foundation; history

$\mathrm{T}$ HE William P. Van Wagenen Fellowship is an annual award from the AANS and administered by the Neurosurgery Research and Education Foundation (NREF) that is open to neurosurgical trainees with an interest in pursuing a career in academic neurosurgery. Considered by many to be the premier award for young neurosurgeons, the fellowship was established with a bequest from Dr. Van Wagenen's will. First awarded in 1968, the fellowship has since been granted to more than 50 neurosurgeons. The fellowship has provided a foundation for the academic and career development of many leaders in our field. The educational opportunities afforded by the fellowship have led to monumental discoveries, and the fellowship experience has proven instrumental in the advancement of our specialty. The fellowship was created to ensure a legacy of mentorship, innovation, and inter- national collaboration in the ranks of neurosurgery. The experience of fellows over the years has fostered many personal and professional relationships across borders that have made neurosurgery a truly international specialty. The wellspring of Dr. Van Wagenen's commitment to these virtues can be traced back to his early experiences in neurosurgery with his own mentor Dr. Harvey Cushing.

\section{Education and Training}

William Perrine Van Wagenen was born on May 24, 1897 , in the small town of Nunda in upstate New York. His attraction to neuroscience began as a young boy, as his sister suffered from epilepsy. He was an excellent student with a strong commitment to academics and received a full scholarship to Cornell University (1914-1918; Fig. 1). While at

ABBREVIATIONS NREF = Neurosurgery Research and Education Foundation.

SUBMITTED April 22, 2017. ACCEPTED October 30, 2017.

INCLUDE WHEN CITING Published online April 27, 2018; DOI: 10.3171/2017.10.JNS17999. 
Harvard Medical School (1918-1922), his medical and surgical interests led him to Harvey Cushing, with whom he began training in 1924 after completing a surgical intern year in 1923 at Memorial Hospital in New York City and Peter Bent Brigham in Boston. During this time as Cushing's chief resident from 1925 to 1926, Van Wagenen and Cushing developed a strong relationship of mentorship and collaboration that resulted in a lifelong friendship and correspondence. Their relationship also set the stage for Van Wagenen to follow in Cushing's footsteps as a leader in neurosurgery. ${ }^{2}$

Van Wagenen completed his training under Cushing and, with Cushing's recommendation in hand, completed an additional year of surgical training at Rochester General Hospital in Rochester, New York. At a crossroads in his career in 1926, Van Wagenen turned to Cushing for further mentorship. Van Wagenen's interest in neurological surgery far surpassed that in general surgery, and he was interested in developing a neurosurgical practice in upstate New York. ${ }^{2}$ Cushing at a similar point in his career had embarked on a journey of scientific discovery recommended to him by his mentors, William Osler and William Welch. Cushing benefited greatly from his studies abroad with Charles Sherrington and Theodor Kocher, and he conducted groundbreaking research on intracranial pressure under the supervision of Theodor Kocher in the laboratory of Hugo Kronecker. Informed by his own experience, Cushing encouraged Van Wagenen to broaden his knowledge of neuroscience by pursuing a research fellowship in Europe (personal correspondence between Van Wagenen and Cushing, 1926-1928).

Van Wagenen initially applied to the American Field Services Fellowship, which allowed him to study at a French university as part of an exchange program. The American Field Services was an all-civilian volunteer force that evacuated more than 1.2 million casualties during both world wars. Cushing also suggested applying for the Guggenheim Fellowship, another grant available at the time but mostly intended for established surgeons in search of sabbatical support. When these other avenues of funding yielded no support, Van Wagenen set out to study in Europe from 1927 to 1928 with financial support from Cushing (personal correspondence, 1926-1928).

Like many neurosurgeons at that time, Van Wagenen chose to focus his research in neuropathology. Van Wagenen had a strong pathology background from his work with Dr. James Rhoads at Memorial Hospital in New York City, where he and Dr. Rhoads discovered that arachnoid cap cells are the cell of origin of menigiomas. ${ }^{5}$ Van Wagenen began his journey in Munich under Professor Walther Spielmeyer, the successor to the famed German psychiatrist/neuropathologist Alois Alzheimer, who had developed an extensive system of stains for pathological analysis of brain tumors (Fig. 2). Van Wagenen later joined the laboratory of Professor Otfrid Foerster in Breslau, where his intellectual curiosity in epilepsy intensified. What was a childhood curiosity, because of his sister's condition, ultimately blossomed into a career-long clinical interest culminating with his novel technique of corpus callosotomy. ${ }^{6}$ Foerster mentored several other early leaders in neurosurgery, including Wilder Penfield, Percival

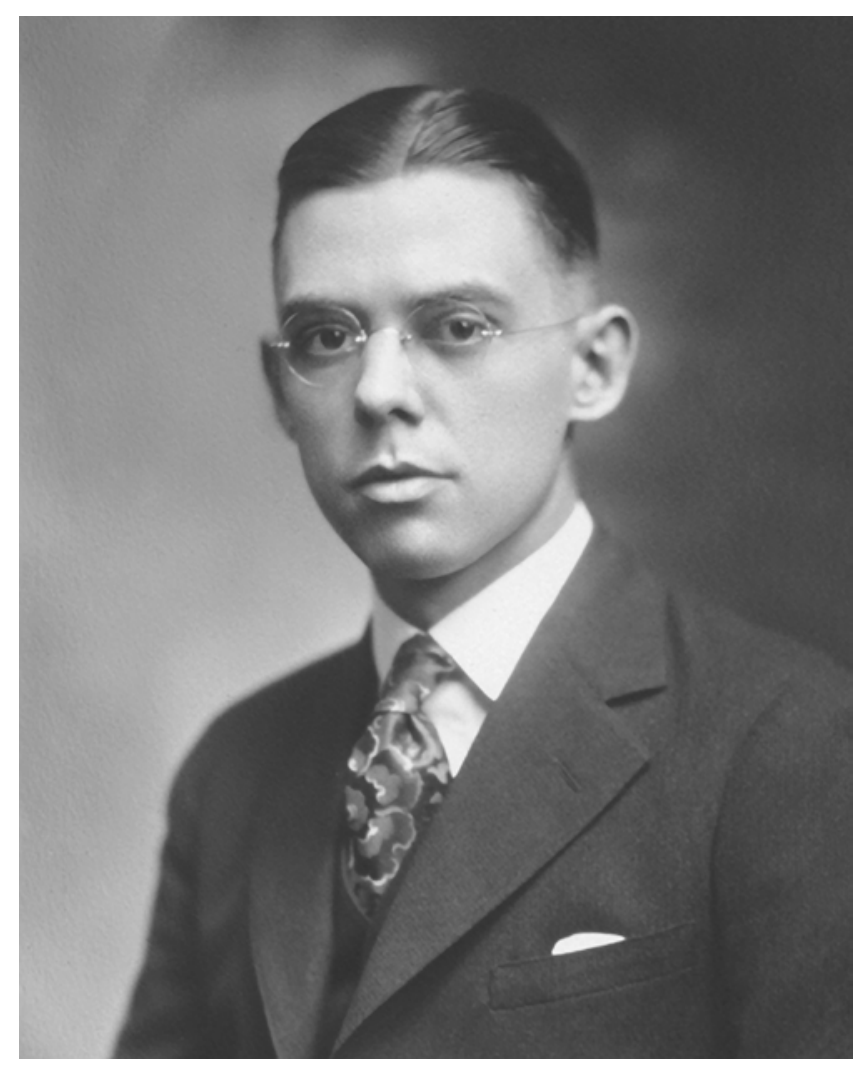

FIG. 1. Photograph of Van Wagenen from the 1918 Cornell University yearbook. Image courtesy of the Van Wagenen family.

Bailey, and Paul Bucy. ${ }^{4}$ Van Wagenen and Wilder Penfield met in Foerster's laboratory and began collaborating on epilepsy research, which resulted in a long-term friendship and mutual respect. In fact, when Van Wagenen became chief of neurosurgery at the University of Rochester, he traveled to visit Penfield at the Montreal Neurological Institute and developed architectural plans for a similar institute in Rochester. ${ }^{2}$

The advances on epilepsy in Foerster's laboratory made a lasting impression on the young Van Wagenen, as is evident in the following quotation from a personal letter to Dr. Cushing: "Had a most profitable...time in Breslau with Professor Foerster. Penfield is there too now. Prof Foerster is doing...very interesting work in epilepsy." (personal correspondence, 1926-1928). Van Wagenen continued to correspond with Cushing regarding Foerster's work, which eventually led to direct international collaboration in the form of Dr. Foerster serving as chief surgeon pro tempore in October 1930 at the Peter Bent Brigham Hospital. ${ }^{4}$

After broadening his research experience and establishing academic connections that would last a lifetime, Van Wagenen returned to the United States to accept an appointment as chief of neurological surgery at the University of Rochester. Dr. Van Wagenen's experiences in Europe had a profound impact on his career as illustrated by his lifelong pursuit of neuroscience, his maintenance of international friendships, and his appetite for traveling to neurosurgical centers to learn techniques and clinical breakthroughs that served as the motivation for creation of the William P. Van Wagenen Fellowship. 


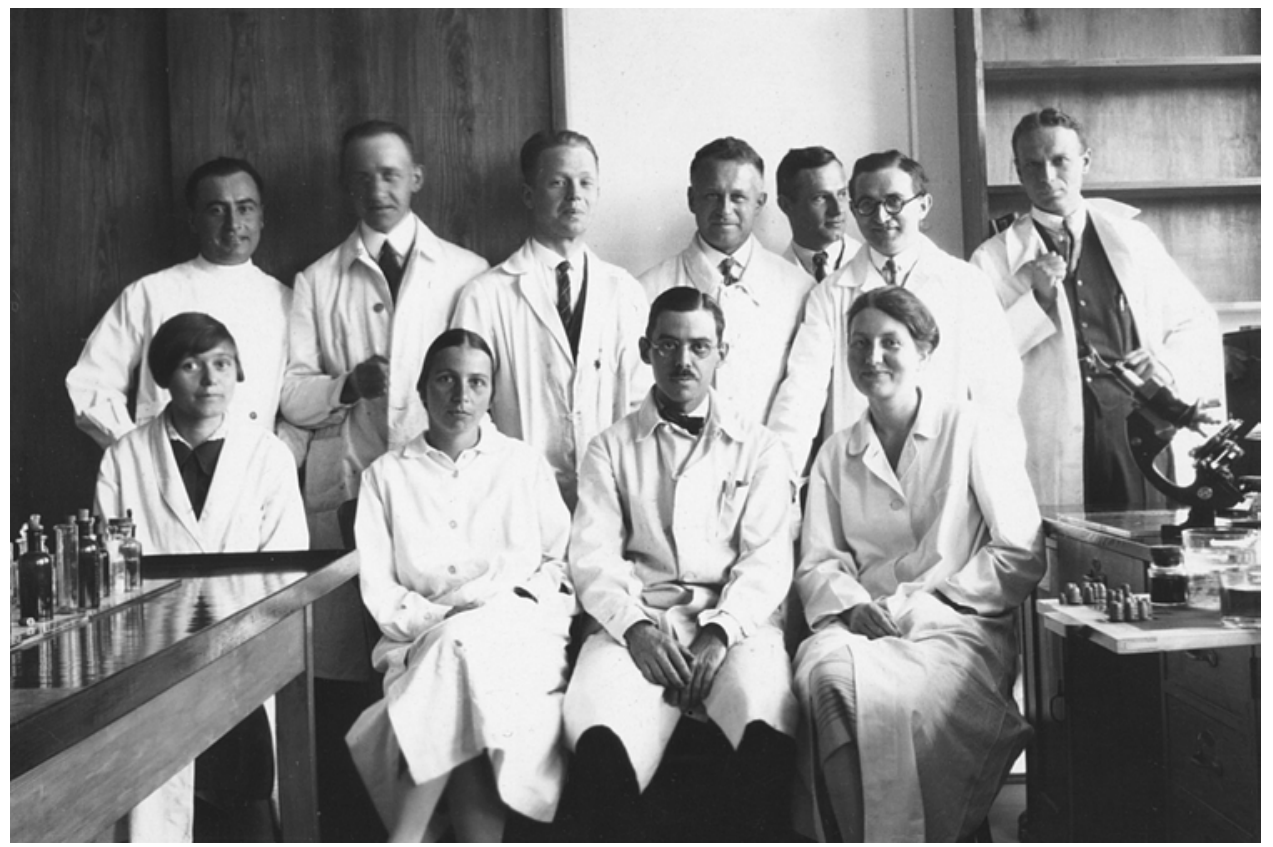

FIG. 2. Photograph of Van Wagenen in the Spielmeyer laboratory in Munich. Dr. Van Wagenen is seated in the center. Image courtesy of the Van Wagenen family.

\section{Creation of the Fellowship}

Dr. Van Wagenen was a founding member and first president of the Harvey Cushing Society (which ultimately became the AANS). His career emphasized the importance of providing the highest quality of neurosurgical care while simultaneously advancing neuroscientific knowledge. His presidential address at the inaugural meeting of the Harvey Cushing Society was titled "Concerning the teaching of Neurological Surgery." Van Wagenen regularly expressed the need to support trainees who would have the freedom to travel for scientific enrichment and observation before starting an academic career without the restrictive project limitations that are frequently associated with other research grants. During his time abroad, Van Wagenen was financially burdened as evidenced by his response to an inquiry of need for additional funding by Harvey Cushing: "I've been on the bottom so long a little longer won't do any harm." (personal correspondence, 1926-1928). Based on his own experience, Van Wagenen believed in the benefit of collaboration with other institutions and scientists from other countries as a means of improving neurosurgical technique, research initiatives, and patient outcomes.

Following his death in 1961, Van Wagenen left detailed instructions in his will for the creation of this comprehensive concept, The William P. Van Wagenen and Abigail R. Van Wagenen Fund (Fig. 3). The will details that the goal of the fellowship was

\footnotetext{
...for the further post-graduate training of individuals who have already completed their resident training, or its equivalent, in neurosurgery or allied fields. The candidates for grants from said fund shall be individuals who give promise of and plan to continue indefinitely in academic or teaching posts in some approved medical school or its hospitals.
}

His wife, Abigail Van Wagenen, with the help of his close friend and trainee at the University of Rochester, Dr. Frank P. Smith, invested the original \$1 million, with detailed contractual arrangements, into an endowment administered by the Harvey Cushing Society. Smith (Fig. 4) spent considerable time after Van Wagenen's death fostering the fellowship's creation from a lump sum of money into a long-term trust. The conditions of the fellowship required the Cushing Society Board of Directors to create a committee. The original committee was composed of Dr. Smith, Dr. Theodore Rasmussen, and Dr. Bronson S. Ray, who served as chairman. The committee was tasked with annually selecting a candidate who showed promise in academic neuroscience, as well as providing an annual status report of the fund to the Harvey Cushing Society. The original endowment also specified that in the event of the dissolution or inability to maintain the fund by the Harvey Cushing Society, management of the endowment would pass to the Society of Neurological Surgeons. The original stipend was $\$ 5000$ and was open to citizens of the North American continent who had completed residency in neurological surgery. The fellow could stay in one center or travel as desired, as long as the duration of study was 6 months or more and a research plan was in place. Throughout the years, attempts to change the conditions of the fellowship were overcome by decisive leadership from the members of the committee, frequently composed of former Van Wagenen fellows, to preserve the original intent of Dr. Van Wagenen's bequest.

During the 1967 annual meeting of the Harvey Cushing Society (now the AANS), the inaugural William P. Van Wagenen Fellowship winner was announced. The first fellow selected was Dr. Richard M. Bergland from Cornell, who had traveled to Oxford University to study pituitary neurophysiology under Professor Geoffrey Har- 
(3) To the Harvey Cuilng Society, Chicago, IIlinols, a copporation organized under the provisions of the General Not for Profft Act of the state of IIlinols and having its regular office at $1 \$ 5$ South La Salle Street, Chicago, Illlnois, for the purposes and on the conditions herein set out, ninety per cent (90\%) of the balance of sald rest, residue and remainder.

Th1s legacy is given under the following oond1tiond:

A. This fund shall be known as "The William P,

Van Wagenen and Abigail R. Van Wagenen Fund".

B. Th1s fund shall be 1nvested by the Board of Directors or their representative in a prudent maner. The principal sura shall not be spent by the Society.

c. The incone from said fund shall be used by The Harvey Cushing Society for the further post-graduate training of Individuals who have already completed their resident training, or its equivalent, in neurosurgery or allied flelds. The oandidates for granta from aald fund ahall be individuals who give promise of and plan to continue indefinitely in academic or teaching posts in some approved medical sohool or its hospitals.

D. Candidates need not neoessarily be oitigens of thip United States of America.

i3. The Board of Directors of the Harvey Cushing Soodety shall administar this fund with whatever technioal assistance from banks or competent financlal advisors they deem prudent. The Board of Directors shall act without fee. They shall select candidates, determine amounts to be paid to each candidate per year, places of study, type and duration of study and other conditions of the grante to be made.

$\therefore$ A yoarly report to the Soodety on the status 2 this fund and its use ahall be made to the mombers of the Harvey Gushing : Hociety alone wth the annul. Treasurer's report.

G. In the evert that the above terme and cond1-

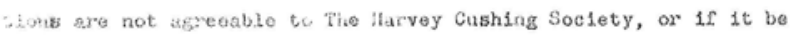
Aissolved or ceaso to runction, the legacy shall bo offered by ny executor or his successor in offlce upon the same terms and conditions to, first, the Society of Neurologtcal Surgeons (U.S.A.) and, second, to the Acadeny of Heurological Surgery (U.S.A.) and, third, to the Society of Neurological Surgeons of North Anerica (U.S.A.)

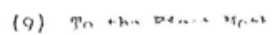

FIG. 3. Page from Dr. Van Wagenen's will detailing the formation of the endowment that would become the William P. Van Wagenen Fellowship. Image courtesy of the Van Wagenen family.

ris. The value of Bergland's experience is illustrated in the following quotation from a letter he wrote to Mrs. Van Wagenen for the 25th Van Wagenen Fellowship Anniversary (http://archive.is/qIsnv):

Your husband's mentors \& heroes - Osler, Halstead [sic], Flexner, Cushing - were the ones who pushed science and international friendships into the mainstream of medicine. How thoughtful it was that he had the wisdom to recognize the importance of this mentor chain. "What is the Van Wagenen Fellowship?" A bridge between the very best old traditions and the very best new traditions. It changed my life and I thank you deeply.

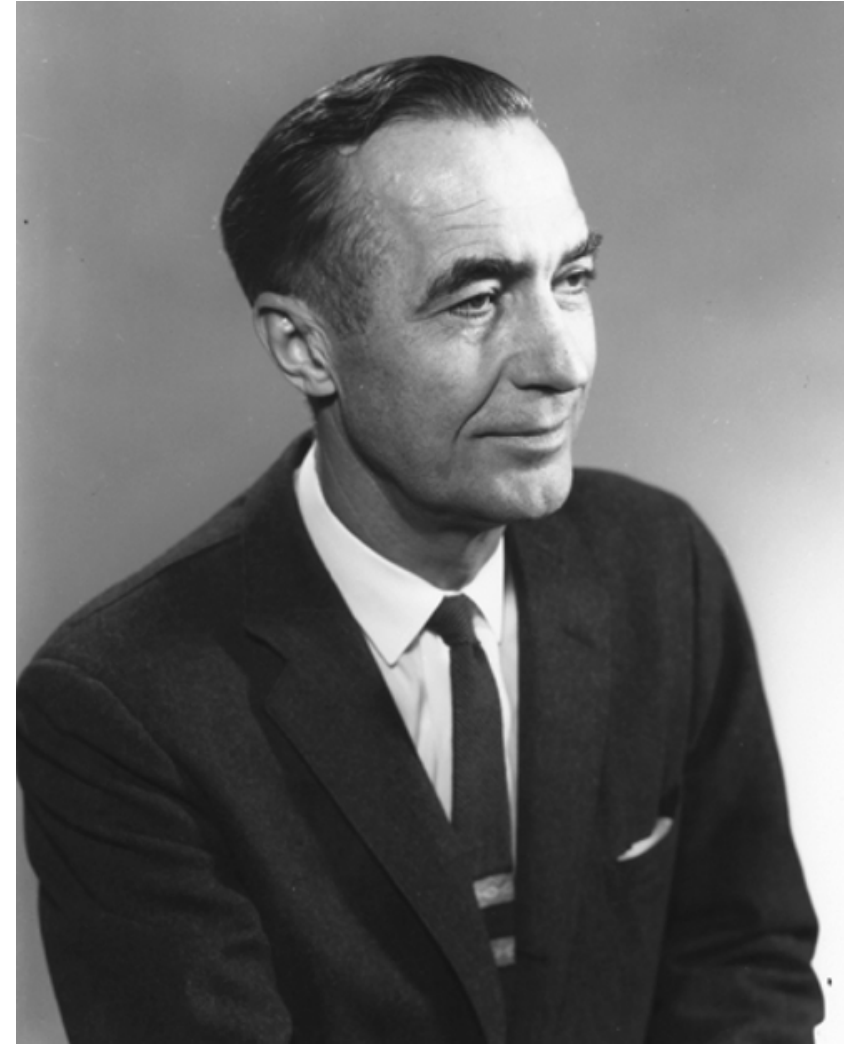

FIG. 4. Frank P. Smith. Steward of the Van Wagenen Fellowship. Image courtesy of the Department of Neurosurgery at University of Rochester.

Over the last 50 years, the annual recipient has been formally announced at the AANS annual meeting. ${ }^{1}$

The fellowship stipend gradually increased from $\$ 5000$ to $\$ 25,000$ in 2000 , when Abigail Van Wagenen died. From the inception of the fellowship until then, the selection of fellows was overseen by the committee selected by the AANS, while funding was provided by Mrs. Van Wagenen herself. This was typically arranged by personal visits to Mrs. Van Wagenen by Dr. Smith, who remained intimately involved in the fellowship even after his retirement from the University of Rochester and relocation to California. Several times during the 1990s, Dr. Smith appealed to the former fellows to make donations to keep the fellowship award in line with inflation. In her will, Mrs. Van Wagenen gifted a very generous sum of money, making the total contribution of Dr. William and Abigail Van Wagenen to the fellowship $\$ 5,350,000$. Upon Abigail's death, Dr. Smith was tasked with securing the financial future of the fellowship. While Abigail's will was in probate, the funds were not available. Dr. Smith was determined to fund a fellow in 2000 and 2001. Thanks again to generous contributions from prior fellows, the deadline was met, and the amount needed was surpassed. Through careful financial stewardship and the generosity of former fellows and other neurosurgeons, the future of the William P. Van Wagenen Fellowship has been sustained and, in fact, the annual stipend has grown steadily to meet the increased cost of living abroad (Frank P. Smith, personal correspondence, 2000). 
As Dr. Smith approached his 85th birthday he wished to ensure the continuity of the Fellowship and its fidelity to Dr. Van Wagenen's initial vision. Working with previous fellows, he initiated the formation of the Collegium of Van Wagenen Fellows. The group, consisting of all former fellows, has met annually since 2001 to participate in the selection of future fellows and advise the Van Wagenen Fellowship Committee on important matters relative to the fellowship.

\section{Impact and Continuing Legacy}

Currently, the William P. Van Wagenen Fellowship is open to senior neurosurgical residents with a commitment to academic neurological surgery. The award provides up to $\$ 120,000$ for living/travel expenses abroad with an additional $\$ 6000$ for family for a period of up to 12 months. In addition, $\$ 15,000$ in research support can be used by the sponsor institution. To facilitate proper planning, applications are submitted by October during the last 2 years of residency through a process administered through the NREF. The Van Wagenen Fellowship Committee, including many prior winners of the award, oversees the fellowship. A selection committee, nominated by the Collegium of Van Wagenen Fellows and reporting to the fellowship committee, is tasked with selecting from a pool of excellent, qualified applicants. ${ }^{1}$

Following in Dr. Van Wagenen's footsteps, the Van Wagenen Fellows have had a strong impact on the neurosurgical field. Past winners include 18 chairmen, as well as numerous chiefs, professors, and assistant professors at neurosurgical programs across the country. In addition to their leadership roles, past fellows' greatest contributions might be their scientific impact. To date, fellows have coauthored more than 4500 publications, with a mean $h$ index of 22 , which is well above the average $h$-index of 16 for academic neurosurgery professors. ${ }^{3}$ Milestone publications in radiosurgery, stereotaxy, pediatrics, epilepsy, neurotrauma, and neurooncology have enhanced patient care. With each passing year, the impact of the fellowship grows, with fellows' ongoing efforts to innovate beyond the work of their forbears.

Over the last 50 years, the 51 recipients of this prestigious award have maximally used its potential to guide their clinical and scientific careers, laying the groundwork for thousands of scientific articles, innovations in neurosurgical technique, international collaborations and friendships, and career-long mentorship. ${ }^{1}$ The Van Wagenen Fellowship continues to serve as an unmatched opportunity to explore new lines of investigation, foster academic and research goals, network with peers, and motivate young neurosurgeons to continue to transform our rapidly changing field. Without question, the legacy of mentorship, scientific inquiry, and clinical excellence personified by Cushing and Van Wagenen is continued by the ongoing recipients of the William P. Van Wagenen Fellowship.

\section{Acknowledgments}

We thank Ms. Chris Philips of the AANS Archive for assistance in obtaining copies of the correspondence between Drs. Cushing, Van Wagenen, and Smith.

\section{References}

1. American Association of Neurological Surgery: William P. Van Wagenen Fellowship. AANS.org. (http://www.aans.org/ Grants $\% 20$ and $\% 20$ Fellowships/The $\% 20$ William $\% 20 \mathrm{P} \% 20$ Van\%20Wagenen\%20Fellowship.aspx) [Accessed January 4, 2018]

2. Kimmell KT, Petraglia AL, Ballou MA, Pilcher WH: William P. Van Wagenen (1897-1961): pupil, mentor, and neurosurgical pioneer. J Neurosurg 119:789-795, 2013

3. Lee J, Kraus KL, Couldwell WT: Use of the $\mathrm{h}$ index in neurosurgery. Clinical article. J Neurosurg 111:387-392, 2009

4. Piotrowska N, Winkler PA: Otfrid Foerster, the great neurologist and neurosurgeon from Breslau (Wrocław): his influence on early neurosurgeons and legacy to present-day neurosurgery. J Neurosurg 107:451-456, 2007

5. Rhoads CP, Van Wagenen WP: Observations on the histology of the tumors of the nervous acusticus. Am J Pathol 4:145-152, 152.1-152.7, 1928

6. Van Wagenen WP, Herren RY: Surgical division of the commissural pathways in the corpus callosum: relation to spread of an epileptic attack. Arch Neurol Psychiatry 44:740-759, 1940

\section{Disclosures}

The authors report no conflict of interest concerning the materials or methods used in this study or the findings specified in this paper.

\section{Author Contributions}

Conception and design: Schmidt, Kimmell, Vates, Pilcher. Acquisition of data: Schmidt, DeAndrea-Lazarus. Analysis and interpretation of data: Schmidt, DeAndrea-Lazarus. Drafting the article: Schmidt, DeAndrea-Lazarus, Kimmell. Critically revising the article: Schmidt, Kimmell, Vates, Haines, Pilcher. Reviewed submitted version of manuscript: Schmidt, Kimmell, Vates, Haines, Pilcher. Approved the final version of the manuscript on behalf of all authors: Schmidt. Administrative/technical/material support: Schmidt, Kimmell, Vates, Haines. Study supervision: Schmidt, Kimmell, Haines.

\section{Correspondence}

Tyler Schmidt: University of Rochester, NY.tyler_schmidt@ urmc.rochester.edu. 